\title{
Factorial analysis of the Multidimensional Health Locus of control scale - form C for elderly
}

\author{
Análise fatorial da Escala Multidimensional de Locus de controle da saúde - \\ forma $C$ para idosos
}

Leani S. M. Pereira', Louise G. Araújo², Rosana F. Sampaio', João P. A. Haddad³

\begin{abstract}
Background: Pain is a multidimensional experience. Locus of control is an important factor related to chronic pain experience and treatment. There is a gap in the literature when discussing issues related to pain evaluation in elderly. Objectives: To analyze the factorial structure, intra and inter-rater reliability of the Brazilian version of the Pain Locus of Control Scale - Form C for elderly with chronic pain living in the community. Methods: One hundred and eighty one elderly individuals ( $71.5 \pm 6.8$ years of age) answered a clinic and socialdemographic questionnaire and the PLOC-C scale. A factorial analysis with varimax rotation of the PLOC-C scale was performed. The scalewas applied twice by two observers to evaluate the intra and inter-rater reliability analyzed using Pearson's Correlation Coefficients. Results: The factorial analysis of the 18 item PLOC-C scale revealed six factors. Four items ( 1 and 6 from the chance locus of control subscale; 2 and 4 from the internal locus of control subscale) migrated toward unpredictable factors in the original factorial structure. Analysis with the removal of the four items demonstrated a better factorial structure and higher levels of internal consistency ( $\alpha=0.836$ and 0.669 ) and reliability (intra-examiner: $r=0.65$ and 0.93 ; inter-examiner: $r=0.82$ and 0.92 ) when compared to the complete subscales. The variance explained was of $48.7 \%$ for the 18 items and $62.4 \%$ for the 14 items scale. Conclusion: The results demonstrate a better applicability of the reduced scale on the sample. The reduced version may contribute to greater knowledge and consequently better chronic pain management in the elderly.
\end{abstract}

Keywords: locus of control; chronic pain; elderly; factorial analysis.

\section{Resumo}

Contextualização: Dor é uma experiência multidimensional. A percepção de locus de controle é um fator importante relacionado à experimentação e ao tratamento da dor crônica. Existe uma lacuna na literatura referente à abordagem de aspectos relacionados à avaliação da dor no idoso. Objetivos: Analisar a estrutura fatorial e a confiabilidade intra e interexaminadores da versão brasileira do instrumento Pain Locus of Control - Forma C (PLOC-C) em idosos comunitários com dor crônica. Métodos: Cento e oitenta e um idosos (71,5 5 ,8 anos) responderam ao questionário clínico e sociodemográfico e à escala PLOC-C. Realizou-se análise fatorial com rotação varimax da escala, que foi aplicada duas vezes por dois examinadores para a observação, por meio do Coeficiente de Correlação de Pearson da confiabilidade inter e intraexaminadores. Resultados: A análise fatorial da PLOC-C, composta por 18 itens, mostrou a expressão de seis fatores. Quatro itens (1 e 6 da subescala de locus de controle ao acaso; 2 e 4 da subescala de locus de controle interno) migraram para fatores imprevisíveis na estrutura fatorial original. Nova análise fatorial, com a retirada dos quatro itens, mostrou melhor estrutura. A variância explicada passou de 48,69\% (18 itens) para 62,38\% (14 itens). A escala reduzida mostrou níveis maiores de consistência interna ( $\alpha=0,836$ e 0,669) e confiabilidade (intraexaminadores: $r=0,65$ e 0,93; interexaminadores: $r=0,82$ e 0,92). Conclusão: Observou-se uma melhor aplicabilidade da versão da escala reduzida na amostra pesquisada. A versão reduzida poderá contribuir para um maior conhecimento e melhor abordagem da dor crônica em idosos.

Palavras-chave: locus de controle da dor; dor crônica; idosos; análise fatorial

Received: 08/23/2010 - Revised: 02/20/2011 - Accepted: 03/25/2011

'Physical Therapy Department, Escola de Educação Física, Fisioterapia e Terapia Ocupacional, Universidade Federal de Minas Gerais (UFMG), Belo Horizonte, MG, Brasil ${ }^{2}$ Physical Therapy Department, Centro Universitário de Belo Horizonte (UNI-BH), Belo Horizonte, MG, Brasil 


\section{Introduction : $:$.}

Pain is a common symptom in the elderly suffering from chronic dysfunctions and thus, is an important worldwide concern $^{1,2}$. Brazilian population surveys have shown that more than $60 \%$ of elderly individuals have chronic diseases that may cause pain ${ }^{2-4}$.

Pain is a multidimensional experience, involving physiological, biochemical, psychological, cultural, religious, cognitive, affective and environmental aspects ${ }^{5}$. Previous lived experiences may influence beliefs, attitudes and meanings that can generate diverse effects on pain expression ${ }^{5-7}$.

Among the factors related to pain perception, the pain locus of control (LC) stands out. LC is based on the social learning theory proposed by Rotter ${ }^{8}$ that defends the theory that personal success or failure experiences previously lived, trigger on the subject a relatively stable perception about the origin and control of things he or she experiences ${ }^{8}$.

The literature describe two major perceptions of control of life events in which the subject can believe predominantly. Subjects with Internal Locus of Control (ILC) believe that life events are controlled by them selves ${ }^{9}$. External Locus of Control (ELC) is divided in chance control (belief that life events are controlled by factors as luck or fate) and by other people (belief that who controls the events are health professionals, relatives and other people $)^{10}$.

In Brazil, few studies that used the construct of LC of health and pain have been published and none of them evaluated this construct primarily in the elderly.

Several scales aiming to evaluate health LC have been developed and, among them is the commonly used Multidimensional Health Locus of Control Scale (MHLC), Forms A and B, proposed by Wallston, Wallston and DeVellis ${ }^{9}$. The MHLC was developed to assess the perception of general health LC and is widely used in different populations ${ }^{11-14}$. However, it has been argued that there are differences in the LC perception of general health when compared to specific health conditions and dysfunctions ${ }^{10,14,15}$. Therefore, Wallston, Stein and $\mathrm{Smith}^{10}$ proposed the MHLC- Form C to evaluate specific health situations like pain ${ }^{9}$.

An evaluation of the international literature demonstrates that the MHLC- Form C have been used on several methodological studies ${ }^{12-14,16-19}$, observationa ${ }^{16,11,20,21}$ andexper imental ${ }^{11,15}$ which strenghtens its applicability.

The theoretical construct of the LC scales have been verified by the use of exploratory factorial analysis ${ }^{14,22,23}$.

The Form $\mathrm{C}$ of the MHCL has been applied in adults (41-55 years old) with multiple chronic pain and health conditions of various etiologies. The exploratory factorial analysis demonstrated four dimensions of the scale: internal, chance, other people and health professionals LC. This form has been found to have good internal consistency of $\alpha>0.7$ in all dimensions and a test-retest reliability ranging from moderate to strong $(0.40 \text { a } 0.80)^{10}$.

Subjects who perceive mainly the pain ELC (by other people or by chance) have been found to have less ability in controlling the pain, greater functional and psychological disability and require a more intense direct supervision of heath professionals. They use coping strategies based on rest, prayers and catastrophism and better adherence to drug therapy rather than to other therapeutic approaches ${ }^{6,11,19,20,24}$ Subjects with a ILC preferential perception have been found to have better ability to control the pain and to perceive health in a positive ways. They better adhere to treatments focused on recommendations and change of habits, use more copping strategies focused on the problem and show higher functional, psychological, and social integration capacities $^{10,14,16,21,25}$.

In this context, the development and adequacy of instruments that assess aspects of perception of chronic pain in elderly become relevant ${ }^{1,11}$. Pain LC is important since it considers the individual perception of pain control and makes it possible to predict health-related behaviors. From a clinical perspective (preventive and curative) the LC has been shown to be modifiable with specific therapeutic approaches that promoted a better ability to deal with pain ${ }^{10-12}$.

The purposes of the present study were to analyze the factorial structure and to observe the intra and inter-rater reliability of the Brazilian version of the MHLC - Form C (Pain Locus of Control Scale - PLOC-C) in adwelling community of elderly individuals with chronic pain.

\section{Methods::}

An exploratory methodological study was conducted with 181 elderly (71.5 \pm 6.8 ; years old). The inclusion criteria were that individuals had to be Brazilian, living in the community, have non-cancer chronic pain for more than three months and be clinically stable. Patients were excluded if they were institutionalized, with acute pain or diseases, visual and or hearing deficits and cognitive impairments assessed by the Mini-Mental State Exam ${ }^{26}$. All participants signed an informed consent before participation.

Elderly individuals were selected by convenience and answered a clinical and social-demographic questionnaire and the PLOC - C scale. Data collection were conducted in specialized clinics for pain treatment $(n=45)$, physical therapy outpatient centers $(n=46)$ and comunitty groups for the elderly $(\mathrm{n}=90)$. The PLOC $-\mathrm{C}$ was previously translated and 
adapted for the Brazilian elderly population by the authors of this study ${ }^{27}$.The instruments were applied by two trained physical therapists.

In order to analyze the inter-rater reliability, two examiners applied the scale at different times during the first day of evaluation. To analyze the intra-rater reliability, the scale was applied on a second occasion, with a maximum five days interval from the initial evaluation, and were conducted independently and blinded from the initial results. Individuals were instructed no to start additional therapies between evaluations. Given the low levels of education among Brazilian elderly, the scale was administered in a interview format.

PLOC - C is composed of 18 items divided into four LC sub-scales: perception of internal (6 items), chance (6 items), other powerful: doctors and health professionals (3 items) and other people (3 items). Considering the low education level of Brazilians elderly, a visual scale was used for scoring, with only four options of response: "strongly disagree" (1 point), "slightly disagree" (2 point), "slightly agree" (3 points) and "strongly agree" (4 points). Each subscale received an independent score that could range from 6 to 24 for the internal and chance LC subscales and from 3 to 12 for the health professionals and other people LC subscales. Each subscale can be applied separately and the higher its score the greater the LC on the dimension. The application of the scale followed the recommendations described on the study of translation and transcultural adaptation of the scale for the Brazilian elderly population ${ }^{27}$. The prevailing perceptions of pain control were analyzed considering the subscales with higher scores.

This study was approved by the Ethics Committee of Research from the Universidade Federal de Minas Gerais (UFMG), Belo Horizonte, MG, Brasil, n 110/06.

\section{Statistical methods}

Measures of central tendency, dispersion and frequency distribution were used to characterize the sample.

The PLOC - C results for 181 elderly were included in a factorial analysis. The sample size was based on the criteria established by Hair et al. ${ }^{28}$ that indicates the need to include ten subjects for each item contained on the scale. The same sample was used for the analysis of internal consistency through the Cronbach Alpha Coefficient.

Pearson's Correlation Coefficients (PCC) were used to evaluate reliability as this was the method used on the original study of the scale. The data met the assumptions for the PCC analysis (linear relationship between variables, homocedacidade and variability of variables).
The sample size calculation for reliability indicated the need to include 22 elderly, considering a significant correlation $\geq 0.5$, a power of 0.8 and a significance level of $\alpha=0.05$. The interpretation of this analysis followed the criteria suggested by Tiboni ${ }^{29}$.

An exploratory factorial analysis of the main components, with orthogonal varimax rotation was used to evaluate construct validity. The adequacy of the data for the use of this analysis was verified by the Kaiser-Meyer-Olkin (KMO) criteria and by the Bartlett test ${ }^{23}$.

The variables that showed an eingenvalue greater or equal to 1 (one) were considered relevant to the extraction of the factors. Only the items of the scale with a factor load greater than 0.45 were included in the factors. This value was set from the sample size $(n=181)$, considering a power of 0.8 and a significance level of $\alpha=0.05^{29}$ (SPSS statistical software package, 13.0 version).

\section{Results : :}

Clinical and social-demographic data are presented on Table 1.

On the factorial analysis Factor 1 grouped the items of the scale concerning the chance LC and showed an internal consistency of $\alpha=0.759$. The items number 2 and 4 from the subscale showed higher factorial load in a different factor from the originally predicted.

Factor 2 grouped the items concerning the internal LC and showed an internal consistency of $\alpha=0.665$. The items number 1 and 6 from the subscale showed higher factorial load in a different factor from the originally predicted.

Factor 3 grouped the items concerning the doctors and health professionals LC, and showed an internal consistency of $\alpha=0.717$. Factor 4 grouped the items concerning other people LC and showed an internal consistency of $\alpha=0.664$. On these two subscales, all items converged with satisfactory factorial loads only for the factors predicted on the original scales.

The PLOC - C factorial analysis composed by 18 items showed the presence of six factors. This analysis with their respective factorial loads, eigenvalues, percentage of variance explained and Cronbach Alpha Coefficient are shown on Table 2. On the factorial analysis of the scale with 18 items, the four predicted factors explained $48.7 \%$ of the total variance.

The exclusion of item 1 contributed to an increase of the internal consistency of the internal LC subscale ( $\alpha=0.665$ to $\alpha=0.670$ ). The same was observed with the item 2 exclusion of chance LC subscale which led to an increase in internal 
Table 1. Clinical and social-demographic profile of the studied sample $(\mathrm{n}=181)$.

\begin{tabular}{|c|c|c|}
\hline Variables & $n$ & $\%$ \\
\hline \multicolumn{3}{|l|}{ Gender } \\
\hline Female & 159 & 87.8 \\
\hline Male & 22 & 12.2 \\
\hline \multicolumn{3}{|l|}{ Age (years-old) } \\
\hline $\begin{array}{l}\text { Mean } \pm \text { standard deviation } \\
\text { (minimum-maximal) }\end{array}$ & $71.5 \pm 6.8(60-91)$ & \\
\hline \multicolumn{3}{|l|}{ Marital Status } \\
\hline Married & 69 & 38.1 \\
\hline Single & 16 & 8.8 \\
\hline Widowed & 84 & 46.4 \\
\hline Divorced & 12 & 6.6 \\
\hline \multicolumn{3}{|l|}{ Educational level } \\
\hline 0 years & 23 & 13 \\
\hline 1 to 7 years & 116 & 64 \\
\hline 8 or more years & 42 & 23 \\
\hline \multicolumn{3}{|l|}{ Family arrangement } \\
\hline Alone & 33 & 18.2 \\
\hline Husband/wife and children & 66 & 36.4 \\
\hline Children and grandchildren & 72 & 40 \\
\hline Others & 10 & 5.4 \\
\hline \multicolumn{3}{|l|}{ Financial income } \\
\hline No income & 18 & 10 \\
\hline Until 2 minimum wages & 115 & 63.5 \\
\hline 2 to 5 minimum wages & 32 & 17.7 \\
\hline 5 to 10 minimum wages & 16 & 8.8 \\
\hline \multicolumn{3}{|l|}{ Location of the major pain } \\
\hline Cervical spine/ head and face & $11 / 3$ & $6 / 1.7$ \\
\hline Upper limband shoulder & 40 & 22 \\
\hline Thoracic spine & 7 & 3.8 \\
\hline Lumbar spine & 33 & 18.2 \\
\hline Pelvis and hip & 9 & 5 \\
\hline Lower limb & 63 & 34.8 \\
\hline Foot & 15 & 8.5 \\
\hline \multicolumn{3}{|l|}{ Length of pain evolution (years) } \\
\hline $\begin{array}{l}\text { Mean } \pm \text { standard deviation } \\
\text { (minimum-maximal) }\end{array}$ & $9.57 \pm 10.60(0.5-51)$ & \\
\hline \multicolumn{3}{|l|}{ Major clinical diagnosis } \\
\hline Osteoarthritis & 110 & 60.8 \\
\hline $\begin{array}{l}\text { Osteoporosis and osteoporotic } \\
\text { fractures }\end{array}$ & 16 & 8.8 \\
\hline Inflammatory musculoskeletal changes & 22 & 12.2 \\
\hline Fibromyalgia & 8 & 4.4 \\
\hline Other rheumatological disease & 6 & 7.4 \\
\hline Neurological dysfunctions & 17 & 9.4 \\
\hline Unknow origin & 2 & 1.1 \\
\hline \multicolumn{3}{|l|}{ Number of associated diseases } \\
\hline $\begin{array}{l}\text { Mean } \pm \text { standard deviation (minimum- } \\
\text { maximal) }\end{array}$ & $4.79 \pm 2.11(0-10)$ & \\
\hline \multicolumn{3}{|l|}{ Intensidade da dor (VAS) } \\
\hline $\begin{array}{l}\text { Mean } \pm \text { standard deviation } \\
\text { (minimum-maximal) }\end{array}$ & $4 \pm 2(1-10)$ & \\
\hline \multicolumn{3}{|l|}{ Self-rated health perception } \\
\hline Very good and good & 98 & 54 \\
\hline Neither good nor poor & 70 & 39 \\
\hline & 13 & 7 \\
\hline \multicolumn{3}{|l|}{ Perception of pain's influence in life } \\
\hline Much & 75 & 41.5 \\
\hline Neither much nor little & 58 & 32 \\
\hline Little & 48 & 26.5 \\
\hline
\end{tabular}

consistency from $\alpha=0.759$ to $\alpha=0.779$. The exclusion of the item 4 from this subscale increased the internal consistency from $\alpha=0.759$ to $\alpha=0.786$. The exclusion of item 6 from the internal LC subscale did not increase the internal consistency of the subscale ( $\alpha=0.665$ to $\alpha=0.635$ ).

Considering the inexpressive factorial load $(<0.45)$ of the above mentioned excluded items on the predicted factors, it was discussed with the author of the original scale the possibility of exclusion of these items. After the author's authorization, a new factor analysis with the exclusion of the items 1,2, 4 and 6 items was conducted. The results concerning this analysis are presented on Table 3. The new factorial analysis showed that without the four items the variance explained by the four predicted factors changed from $48.7 \%$ with 18 items to $62.4 \%$ with 14 items.

Table 4 shows the values of intra and inter-rater reliability of the complete and of the reduced subscales of LC.

\section{Discussion $: \because$.}

The new scale containing 14 items showed better factorial structure, internal consistency and reliability than the complete scale with 18 items.

The factorial analysis of the complete scale showed important factorial loads in other factors, the four items 1 and 6 from the internal LC subscale and 2 and 4 from the chance LC subscale, different from those predicted in the original scale.

According to Skinner ${ }^{30}$, the sense of control of a situation is given by two elements: the belief in the strategy (the subject believes that a determined action leads to a result that controls the situation) and the belief in the capacity (subject believes that he or she has the skills to produce the result that controls the situation $)^{30}$. The social learning theory, in which is based the pain and health LC, suggests that the LC is a belief in the strategy $^{12}$. However, Baken and Stephens ${ }^{17}$, using a factorial analysis, found that the health LC scale (Form A) contains items that cover both the belief in capacity and strategy.

In this study, the item number 1: "If my pain worsens, it is my own behavior which determines how soon I will feel better again" and number 6: "I am directly responsible for my pain getting better or worse" from the internal LC subscale, when compared to the other items from the subscale, showed a greater emphasis on the belief in individual capacity to relieve the pain. The expressions "it is my own behavior" and "I am directly responsible" reinforce the idea that the capacity to improve or worsen the pain is based on a personal action. Possibly, the belief in the personal capacity to relieve pain may have contributed to these items convergence to an unpredicted factor in the factorial analysis. 
Table 2. PLOC-C Scale with 18 items - Factorial solution with factorial loadings, eigenvalues, percentage of variance and Cronbach Alpha Coefficient. Portuguese version.

\begin{tabular}{|c|c|c|c|c|c|c|}
\hline \multirow[b]{2}{*}{ Items } & \multicolumn{6}{|c|}{ Factors } \\
\hline & 1 & 2 & 3 & 4 & 5 & 6 \\
\hline 1) Se a minha dor ficar pior, é o que eu fizer que vai me fazer melhorar rápido ou devagar. & 0.000 & 0.096 & 0.197 & -0.046 & 0.769 & 0.262 \\
\hline 2) Pensando na minha dor, o que tiver que acontecer vai acontecer. & 0.165 & 0.007 & -0.056 & 0.014 & -0.011 & 0.873 \\
\hline 3) Se eu consultar meu médico regularmente, vou ter menos problemas com minha dor. & 0.025 & 0.072 & 0.667 & 0.297 & 0.175 & -0.196 \\
\hline $\begin{array}{l}\text { 4) A maioria das coisas que afetam a minha dor acontece por acaso (ou seja, sem motivo, à toa, } \\
\text { porque tem que ser). }\end{array}$ & 0.188 & 0.129 & -0.037 & -0.022 & 0.577 & 0.239 \\
\hline 5) Toda vez que minha dor ficar pior, eu devo consultar um profissional de saúde. & 0.096 & 0.078 & 0.841 & 0.059 & -0.012 & -0.012 \\
\hline 6) Sou eu que posso melhorar ou piorar a minha dor. & -0.021 & 0.370 & -0.086 & 0.223 & 0.592 & -0.118 \\
\hline $\begin{array}{l}\text { 7) Outras pessoas (amigos, familiares, acompanhante, cuidadores) são importantes para que a minha } \\
\text { dor melhore, fique igual ou piore. }\end{array}$ & 0.271 & -0.057 & -0.024 & 0.755 & 0.051 & -0.046 \\
\hline 8) Tudo que acontece de errado com a minha dor é por minha culpa. & 0.092 & 0.692 & -0.068 & -0.002 & 0.099 & -0.175 \\
\hline 9) Grande parte da melhora da minha dor é causada pela sorte. & 0.886 & 0.045 & 0.050 & 0.077 & 0.027 & -0.064 \\
\hline 10) Para que minha dor melhore, outras pessoas devem fazer as coisas certas. & -0.009 & 0.025 & 0.118 & 0.716 & -0.002 & 0.123 \\
\hline 11) Qualquer melhora da minha dor é em grande parte por causa da sorte. & 0.907 & 0.120 & 0.061 & 0.134 & -0.008 & 0.009 \\
\hline 12) 0 que mais melhora ou piora a minha dor é o que eu mesmo faço. & 0.109 & 0.693 & 0.079 & -0.120 & 0.257 & 0.108 \\
\hline 13) Eu mereço os parabéns quando minha dor melhora e mereço ser culpado quando ela piora. & 0.089 & 0.710 & 0.125 & 0.206 & -0.123 & 0.204 \\
\hline $\begin{array}{l}\text { 14) Seguir as orientações médicas corretamente (ou seja, fazer o que o médico disse) é o melhor para } \\
\text { não piorar a minha dor. }\end{array}$ & 0.029 & 0.129 & 0.833 & 0.000 & 0.040 & 0.086 \\
\hline 15) Se minha dor ficar pior, é por causa do destino (ou seja, porque tem que ser). & 0.608 & 0.008 & -0.043 & 0.126 & -0.235 & 0.362 \\
\hline 16) Se eu tiver sorte, a minha dor vai ficar melhor. & 0.763 & 0.104 & 0.091 & 0.128 & -0.095 & 0.167 \\
\hline 17) Se minha dor ficar pior, é porque não cuido bem de mim. & -0.004 & 0.680 & 0.227 & 0.084 & -0.053 & -0.024 \\
\hline $\begin{array}{l}\text { 18) } 0 \text { tipo de ajuda que recebo de outras pessoas (amigos, familiares, cuidadores, acompanhante) faz } \\
\text { minha dor melhorar mais rápido ou mais devagar. }\end{array}$ & 0.169 & 0.191 & 0.161 & 0.748 & 0.054 & -0.064 \\
\hline \multicolumn{7}{|l|}{ eigenvalue } \\
\hline$\%$ variance explained & 2.65 & 2.14 & 2.04 & 1.98 & 1.49 & 1.31 \\
\hline Total variance accounted for 4 factors: $48.69 \%$ & $(14.74)$ & $(11.89)$ & $(11.36)$ & $(10.70)$ & $(8.29)$ & $(7.30)$ \\
\hline $\begin{array}{l}\text { Cronbach Alpha Coefficient } \\
\text { Total: } 0.748\end{array}$ & 0.759 & 0.665 & 0.717 & 0.664 & & \\
\hline
\end{tabular}

Factor 1: chance locusof control; Fator 2: internal locus of control; Fator 3: healthcare professionals locus of control; Fator 4: other people locus of control.

Table 3. PLOC-C Scale with 14 items - Factorial solution with factorial loadings, eigenvalues, percentage of variance and Cronbach Alpha Coefficient. Portuguese version.

\begin{tabular}{|c|c|c|c|c|}
\hline \multirow{2}{*}{ Items } & \multicolumn{4}{|c|}{ Factors } \\
\hline & 1 & 2 & 3 & 4 \\
\hline 3) Se eu consultar meu médico regularmente, vou ter menos problemas com minha dor. & -0.038 & 0.065 & 0.714 & 0.301 \\
\hline 5) Toda vez que minha dor ficar pior, eu devo consultar um profissional de saúde. & 0.091 & 0.083 & 0.833 & 0.056 \\
\hline $\begin{array}{l}\text { 7) Outras pessoas (amigos, familiares, acompanhante, cuidadores) são importantes para que a minha } \\
\text { dor melhore, fique igual ou piore. }\end{array}$ & 0.257 & -0.062 & -0.004 & 0.758 \\
\hline 8) Tudo que acontece de errado com a minha dor é por minha culpa. & 0.030 & 0.693 & -0.053 & 0.030 \\
\hline 9) Grande parte da melhora da minha dor é causada pela sorte. & 0.837 & 0.067 & 0.060 & 0.107 \\
\hline 10) Para que minha dor melhore, outras pessoas devem fazer as coisas certas. & 0.019 & 0.035 & 0.101 & 0.715 \\
\hline 11) Qualquer melhora da minha dor é em grande parte por causa da sorte. & 0.881 & 0.131 & 0.074 & 0.146 \\
\hline 12) 0 que mais melhora ou piora a minha dor é o que eu mesmo faço. & 0.073 & 0.752 & 0.077 & -0.091 \\
\hline 13) Eu mereço os parabéns quando minha dor melhora e mereço ser culpado quando ela piora. & 0.148 & 0.695 & 0.099 & 0.181 \\
\hline $\begin{array}{l}\text { 14) Seguir as orientaç̃ões médicas corretamente (ou seja, fazer } 0 \text { que o médico disse) é o melhor para } \\
\text { não piorar a minha dor. }\end{array}$ & 0.053 & 0.132 & 0.832 & -0.029 \\
\hline 15) Se minha dor ficar pior, é por causa do destino (ou seja, porque tem que ser). & 0.716 & -0.005 & -0.066 & 0.070 \\
\hline 16) Se eu tiver sorte, a minha dor vai ficar melhor. & 0.801 & 0.103 & 0.089 & 0.104 \\
\hline 17) Se minha dor ficar pior, é porque não cuido bem de mim. & 0.009 & 0.675 & 0.209 & 0.075 \\
\hline $\begin{array}{l}\text { 18) } 0 \text { tipo de ajuda que recebo de outras pessoas (amigos, familiares, cuidadores, acompanhante) faz } \\
\text { minha dor melhorar mais rápido ou mais devagar. }\end{array}$ & 0.146 & 0.209 & 0.162 & 0.765 \\
\hline \multicolumn{5}{|l|}{ eigenvalue } \\
\hline$\%$ variance explained & 2.76 & 2.09 & 2.01 & 1.86 \\
\hline Total variance accounted for 4 factors: $62.38 \%$ & $(19.72)$ & $(14.95)$ & $(14.40)$ & $(13.30)$ \\
\hline $\begin{array}{l}\text { Cronbach Coefficient Alpha } \\
\text { Total: } 0.768\end{array}$ & 0.836 & 0.669 & 0.717 & 0.664 \\
\hline
\end{tabular}

Factor 1: chance locus of control. Fator 2: internal locus of control. Fator 3: health care professionals locus of control. Fator 4: other people locus of control. 
Table 4. Results from the intra and inter-rater reliability analysis through the Pearson's Correlation Coefficients (PCC) of the complete and reduced subscales.

\begin{tabular}{lcccc}
\hline & $\begin{array}{c}\text { Intra-rater } \\
18 \text { itens }\end{array}$ & $\begin{array}{c}\text { Intra-rater } \\
14 \text { itens }\end{array}$ & $\begin{array}{c}\text { Inter-rater } \\
18 \text { itens }\end{array}$ & $\begin{array}{c}\text { Inter-rater } \\
14 \text { itens }\end{array}$ \\
\hline Locus of control subscale & & & & $0.82^{*}$ \\
\hline Internal & $0.72^{*}$ & $0.65^{*}$ & $0.79^{*}$ & $0.92^{*}$ \\
\hline Chance & $0.90^{*}$ & $0.93^{*}$ & $0.90^{*}$ & $0.80^{*}$ \\
\hline Health care professional & $0.93^{*}$ & $0.93^{*}$ & $0.80^{*}$ & $0.72^{*}$ \\
\hline Other people & $0.60^{*}$ & $0.60^{*}$ & $0.72^{*}$ & \\
\hline
\end{tabular}

${ }^{*} p<0.0001$.

The contextualization and interpretation of items 1 and 6 may also have interfered on the factorial structure found in this study. In the answers given by the elderly, some items were cited as actions developed to relieve the pain: take medicine, go to the physical therapy or doctor, put ice and do a prayer. These actions may be confused with other beliefs of control. Many elderly had difficulties in choosing an accurate answer on item 6 because they agreed that their actions can only relieve or worsen the pain. The difficulties in interpreting and in choosing the answers in these items may have favored a small factorial load in the predicted factor.

On the chance LC subscale the item number 2: "As to my pain, what will be will be and number 4: "Most things that affect my pain happen to me by chance" showed high factorial loads in factors that were not predicted on the factorial structure of the original scale. While applying the scale, a difficulty in the comprehension of the expressions "what will be will be" and "happen to me by chance" by the elderly was noticed. Many elders reported during the answers that these expressions were related to God's will. The difficulty to interpret the idea of divinity brought up by these expressions may have contributed for the convergence of these items to unpredicted factors. Positive correlations between chance and God LC were already observed in previous studies ${ }^{31,32}$. Elderly individuals used strategies, such as prayers, to deal with ageing and chronic pain ${ }^{33,34}$. The presence of a fifth LC, in God, is defended as a belief of control independent from the other people $\mathrm{LC}^{12,14,16,17}$. It was found that $86 \%$ of elders participated in religious activities, what suggests that the idea of divinity raised on the elderly answers may in part justify the factorial structure found. These observations indicate the need to consider God LC perception in the control of elderly's pain, and the importance of observing God LC in this population.

Regarding items number 2 and 4, the translation of the original expressions "what will be will be" and "happen to me by chance" may have failed to reproduce the original idea proposed to the American culture, even after a discussion with a committee of experts. The elderly had lower education level when compared to those from the original study ${ }^{10}$. Social and cultural differences may also have hindered the understanding of the scale ${ }^{10,35}$.

Finally, the factorial structure observed may have suffered influence from other beliefs of control already described on the literature and not covered in this scale, such as LC of genetics, physical environment, psychological, financial condition, professional activity and supernatural sources of control ${ }^{12,17}$.

Different factorial structures from the LC of health and pain scale were already found in previous studies reinforcing the need to use factorial analysis as a procedure of validation of scales, for their use in different cultures and populations ${ }^{14,16,18,19,36}$.

The factorial analysis of the scale containing 14 items proved to be adequate to the expected model. All items were gathered on the factor predicted initially with factorial loads higher than 0.69 on the corresponding factor and lower than 0.3 on the other factors. The exact convergence of the items to the expected factor strengthens the evidence that the new scale explains better the theoretical construct of pain LC for this population. These finds were confirmed with an increase of the total variance explained with the four factors in the form with 14 items. The factorial analysis observed in this study strengthens the separation of the subscale "other powerfull" in two dimensions: "doctors and health professionals" and "other people", as observed on the original scale ${ }^{10}$.

Previous studies mentioned the possibility of a decrease in internal consistency with the exclusion of items from a scale $^{12,18}$. In this study, the exclusion of items 2 and 4 from the chance LC subscale increased the internal consistency from $\alpha=0.759$ to $\alpha=0.836$. In the internal LC subscale, the exclusion of items 1 and 6 increased the internal consistency from $\alpha=0.665$ to $\alpha=0.669$.

In this study, the internal consistency from the chance, other people and doctors/health professionals LC subscales showed higher values than those observed on the internal LC subscale. This result differs from those found by other authors who observed higher internal consistency in the internal LC subscale $^{9,10,12,37}$. However, Gibson and Helme ${ }^{11}$ and RobinsonWhelen and Storandt ${ }^{13}$, while analyzing the internal consistency of Form A and B from the MHLC scale adapted to the 
pain of elderly people, observed lower values in the internal LC subscale when compared to the other subscales ${ }^{11,13}$.

The results showed that the ELC subscales (by chance and other people) had internal consistencies similar or higher than those obtained on the subscales originally proposed by Wallston, Stein and Smith ${ }^{10}$. On the chance LC subscale, the internal consistency increased from $\alpha=0.79$ to $\alpha=0.836$. For the subscales that were not changed, the values found were similar $(\alpha=0.71)$ for the doctors LC sub scale or very similar for the other people LC $(\alpha=0.664$ in the present study and $\alpha=0.70$ in the Wallston, Stein and Smith ${ }^{10}$ study). The internal LC subscale showed an internal consistency lower $(\alpha=0.669)$ than that obtained in the original study $(\alpha=0.85)^{10}$. However, as proposed by Williams ${ }^{38}$, this subscale continued to be classified with good and very good internal consistency (0.6-0.85).

The reliability analysis of the new scale demonstrated higher Pearson's correlation coefficient when compared to Wallston, Stein and Smith ${ }^{10}$ results. The later found regular to strong test-retest reliability on the subscales evaluated on a six weeks interval: 0.80 in the internal LC subscale, 0.72 in the chance LC, 0.58 in LC in health professionals and 0.40 in LC in other people ${ }^{10}$. Possibly, larger time intervals used between the applications of the scale contributed to these results.

The results also showed a higher internal consistency and reliability of the chance LC and doctors/health professionals LC subscales, besides a lower consistency and reliability in the answers of internal LC and in other people LC subscales. It can be deduced that the results may be related both to the events and to the daily experiences mentioned by the elderly people, that seemed to influence the perceptions of pain control such as after carrying excessive weight, cleaning the house, having a pleasant social meeting with a neighbor and after a quarrel with relatives ${ }^{27}$. The reliability of the scale was improved with the exclusion of the items from the internal and chance LC subscales.

Based on these results, it is recommended that the application of the Pain Locus of Control Scale for elderly people is performed in an interview format, excluding items 1, 2, 4 and 6 , using a visual scale for the answers and allowing the elderly to give examples to facilitate the choice between the answers. This form of application may contribute to an increase in the internal consistency and to an improvement in the reliability rates of the scale.

Comparisons and discussions of the results of this study with previously published literature was limited due to absence of methodologically sound studies validating the scale studied.

Some limitations of the present study deserve attention such as the use of a convenient sample, composed mainly by women and the inclusion of individuals with primarily musculoskeletal conditions. These factors may have confounded the results of this study.

It can be concluded that the LC of pain scale with 14 items is applicable in a dwelling community of elderly with chronic pain. According to the factorial analysis and to the internal consistencies observed, it can be inferred that the scale has construct validity.

The use of the reduced PLOC -Form $\mathrm{C}$ will allow the conduction of researches and provide greater knowledge about the pain locus of control of the elderly people, enabling a more suitable approach of the chronic pain. Studies with larger samples, randomly selected, with different characteristics and focused in other types of validity are needed to strengthen the applicability of the short Form.

\section{References: ::}

1. Rossetto EG, Dellaroza MSG, Kreling MCGD, Cruz DAL, Pimenta CAM. Epidemiologia da dor em crianças, adultos e idosos. Arq Bras Neurocir. 1999;18(4):213-24.

2. Almeida MF, Barata RP, Montero CV, Silva ZP. Prevalência de doenças crônicas auto-referidas e utilização de serviços de saúde, PNAD/1998, Brasil. Ciênc Saúde Coletiva. 2002;7(4):743-56.

3. Ramos LR. Estudo de seguimento por dois anos de idosos residentes em São Paulo, Brasil: metodologia e resultados preliminares. Rev Saúde Pública. 1998;32(5):397-407.

4. Dellarozza MSG, Pimenta CAM, Matsuo T. Prevalência e caracterização da dor crônica em idosos não institucionalizados. Cad Saúde Pública. 2007;23(5):1151-9.

5. Geertzen JH, Van Wilgen CP, Schrier E, Dijkstra PU. Chronic pain in Rehabilitation Medicine. Disabil Rehabil. 2006;28(6):363-7.

6. Bates MS, Edwards WT, Anderson KO. Ethnocultural influences on variation in chronic pain perception. Pain. 1993;52(1):101-12.

7. Bargiel-Matusiewicz K, Krzyszkowska A. Dispositional optimism and coping with pain. Eur J Med Res. 2009;14 Suppl 4:271-4.

8. Rotter J. A teoria da personalidade social. In: Schultz DP, Schultz SE. Teorias da personalidade. $1^{a}$ ed. São Paulo: Thomson Learning; 2006. p. 414-31.
9. Wallston KA, Wallston BS, DeVellis R. Development of the Multidimensional Health Locus of Control (MHLC) Scales. Heath Educ Monogr. 1978;6(2):160-70.

10. Wallston K, Stein MJ, Smith CA. Form C of the MHLC Scale: a condition-specific measure of locus of control. J Pers Assess. 1994;63(3):534-53.

11. Gibson ST, Helme RD. Cognitive factors and the experience of pain and suffering in older persons. Pain. 2000;85(3):375-83.

12. Wallston K. The validity of the Multidimensional Health Locus of Control Scales. J Health Psycol. 2005;10(5):623-31.

13. Robinson-Whelen S, Storandt M. Factorial structure of two health beliefs measures among older adults. Psychol Aging. 1992;7(2):209-13.

14. O'Hea EL, Bodenlos JS, Moon S, Grothe KB, Brantley PJ. The multidimensional health locus of control scales: testing the factorial structure in sample of African American medical patients. Ethn Dis. 2009;19(2):192-8.

15. Kurita GP, Pimenta CA. Compliance with the treatment of chronic pain and health control locus Rev Esc Enferm USP. 2004;38(3):254-61.

16. Luszczynska A, Schwarzer R. Multidimensional Health Locus of control: comments on the 
construct and its measurement. J Health Pshycol. 2005;10(5):633-42.

17. Baken D, Stephens C. More dimensions for the multidimensional health locus of control: confirmatory factor analysis of competing models of the structure of control beliefs. J Health Psycol. 2005;10(5):643-56.

18. Malcarne VL, Fernandez S, Flores L. Factorial validity of the Multidimensional Health Locus of Control Scales for three american ethinic groups. J Health Psycol. 2005;10(5):657-67.

19. Oliveira VC, Furiati T, Sakamoto A, Ferreira P, Ferreira M, Maher C. Health locus of control questionnaire for patients with chronic low back pain: psychometric properties of the BrazilianPortuguese version. Physiother Res Int. 2008;13(1):42-52.

20. Oliveira VC, Ferreira PH, Ferreira ML, Tiburcio L, Pinto RZ, Oliveira W, et al. People with low back pain who have externalised beliefs need to see greater improvements in symptoms to consider exercises worthwhile: an observational study. Aust J Physiother. 2009;55(4):271-5.

21. Sengul $Y$, Kara B, Arda MN.The relationship between health locus of control and quality of life in patients with chronic low back pain. Turk Neurosurg. 2010;20(2):180-5.

22. Henson RK, Roberts JK. Use of exploratory factor analysis in published research. Common Errors and Some Comment on Improved Practice. Education and Psychological Measurement. 2006;63(3):393-416

23. Mingoti SA. Análise de dados através de métodos de estatística multivariada. $1^{a}$ ed. Belo Horizonte: Editora UFMG; 2005.

24. Cross MJ, March LM, Lapsley HM, Byrne E, Brooks PM. Patients self-efficacy and health locus of control: relationships with health status and arthritis-related expenditure. Rheumatology. 2006:45:92-6.

25. Karoly P, Ruehlman LS. Psychosocial aspects of pain-related life task interference: an exloratory analysis in a general population sample. Pain Medicine. 2007;8(7):563-72.

26. Bertolucci PHF, Brucki SMD, Campacci SR, Juliano Y. Mini-Exame do Estado Mental em uma população geral - impacto da escolaridade. Arq Neuropsiquiatr. 1994;52(1):1-7.
27. Araújo LG, Lima DM, Sampaio RF, Pereira LS. Pain Locus of Control Scale: adaptation and reliability for elderly. Rev Bras Fisioter. 2010;14(5):438-45.

28. Hair Jr JF, Anderson RE, Tathan RL, Black WC. Análise multivariada de dados. 5a ed. Porto Alegre: Bookman; 2005

29. Tiboni CGR. Estatística básica para o curso de turismo. $2^{a}$ ed. São Paulo: Atlas; 2003.

30. Skinner EA. A guide to constructs of control. J Pers Soc Psychol. 1996;71(3):549-70.

31. Wallston KA, Malcarne VL, Flores L, Hansdottir I, Smith CA, Stein MJ, et al. Does god determine your health? The god locus of health control scale. Cognitive Therapy and Research. 1999;23(2):131-42

32. Crisson JE, Keefe FJ. The relationship of locus of control to pain coping strategies and psychological distress in chronic pain patients. Pain. 1988;35(2):147-54

33. Vechia RD, Ruiz T, Bocchi SCM, Corrente JE. Qualidade de vida na terceira idade: um conceito subjetivo. Rev Bras Epidemiol. 2005;8(3):246-52.

34. Dunn KS, Horgas AL. Religious and nonreligious coping in older adults experiencing chronic pain. Pain Manag Nurs. 2004;5(1):19-28

35. Garrido R, Menezes PR. 0 Brasil está envelhecendo: boas e más notícias por uma perspectiva epidemiológica. Rev Bras Psiquiatr. 2004;24(supl 1):3-6.

36. Chaplin WF, Davidson K, Sparrow V, Stuhr J, Roosmalen EV, Wallston KA. A structura evaluation of the expanded multidimensional health locus of control scale with a diverse sample of caucasian/european, native, and black canadian women. J Health Psychol. 2001;6(4):447-55

37. Winefield HR. Reliability and validity of the Health Locus of Control Scale. J Pers Assess. 1982;46(6):614-9.

38. Williams RC. Toward a set of reliable and valid measures for chronic pain assesssment and outcomes research. Pain. 1988;35(3):239-51. 